\title{
Avian and skunk predation of Ashy Storm- Petrels at Santa Cruz Island, California
}

\author{
William R. McIver ${ }^{1,6}$, Harky R. Carter $2,6, \dagger$, A. Laurie Harvey3,7, David M. Mazurkiewicz ${ }^{3}$, \\ Jim A. Howard ${ }^{4}$, Paige L. Martin ${ }^{3,8}$, and John W. Mason 5 \\ ${ }^{1}$ U.S. Fish and Wildlife Service, Arcata Fish and Wildlife Office, 1655 Heindon Road, Arcata, CA 95521 \\ ${ }^{2}$ Carter Biological Consulting, 1015 Hampshire Road, Victoria, British Columbia V8S 4S8, Canada \\ ${ }^{3}$ National Park Service, Channel Islands National Park, 1901 Spinnaker Drive, Ventura, CA 93001 \\ ${ }^{4}$ California Institute of Environmental Studies, 3408 Whaler Avenue, Davis, CA 95616 \\ ${ }^{5}$ Environment International, Ltd., 3835 SE Pelton Ave., Troutdale, OR 97060 \\ ${ }^{6}$ Humboldt State University, Department of Wildlife, 1 Harpst Street, Arcata, CA 95521 \\ 7Present address: Sutil Conservation Ecology, 2408 George Anderson Drive, Hillsborough, NC 27278 \\ 8Present address: 14511 Knoll Ridge Drive, Tampa, FL 33625
}

\begin{abstract}
Avian and mammalian predation of Ashy Storm-Petrels (Oceanodroma homochroa) were documented during monthly nest monitoring in 1995-1998 and 2005-2015 and once-per-year monitoring in 1999-2004 at 5 colonies at Santa Cruz Island, California. Throughout the study period, predation by Barn Owls (Tyto alba) was documented at the sea cave colonies, and at Orizaba Rock, and likely contributed to reduced breeding success at Bat Cave in 1995-1997. Recent predation by Common Ravens (Corvus corax) caused reduced breeding success each year in 2012-2015 at Orizaba Rock (35\%-48\%) and in 2013 and 2015 at Bat Cave (49\%-52\%). Raven predation appears to be developing into a larger long-term problem that may require additional management actions, but efforts have focused on deploying artificial nests at Bat Cave to provide more protected sites. Two sea cave colonies where skunks previously had not been detected experienced major adult mortality due to unusual predation events by island spotted skunks (Spilogale gracilis amphiala) in 2005 and 2008. At Bat Cave in 2005, 2 skunks were trapped after they had killed at least 76 Ashy StormPetrel adults. Prior to this mortality event, the colony contained 64-97 nests per year in 1995-1997, with low breeding success $(49 \%-59 \%)$ related largely to organochlorine pollutants. After the skunks were caught, nest numbers increased from 19 in 2006 to 100 in 2015, with variable but generally higher breeding success (49\%-90\%). At Cavern Point Cove Caves in 2008, 2 skunks were trapped after killing at least 32 adults. Prior to the mortality event, this colony contained 11-17 nests per year in 1995-1997, with a lower breeding success rate of 20\%-47\%. Nest numbers increased from 2 in 2009 to 10 in 2015 , with a variable but higher rate of breeding success (50\%-80\%). Skunk predation events may have been related to temporarily higher skunk populations at Santa Cruz due to low numbers of island foxes (Urocyon littoralis santacruzae). Deer mice (Peromyscus maniculatus santacruzae) were not significant predators of Ashy StormPetrels at Santa Cruz Island.
\end{abstract}

Resumen.-La depredación aviar y mamífera de paínos cenizos (Oceanodroma homochroa) fue documentada durante un monitoreo mensual de nidos en los períodos de 1995-1998 y de 2005-2015, y una vez al año durante el período de 1999-2004, en 5 colonias de la Isla Santa Cruz, California. A lo largo del período de estudio, la depredación por parte de la lechuza común (Tyto alba) se documentó en las colonias de cuevas marinas y en Orizaba Rock, lo que probablemente contribuyó a la reducción del éxito reproductivo en Bat Cave entre 1995-1997. La depredación reciente por cuervos (Corvus corax) probablemente causó la reducción en el éxito reproductivo anual entre el 2012-2015 en Orizaba Rock (35\%-48\%) y en 2013 y 2015 en Bat Cave (49\%-52\%). La depredación por cuervos puede convertirse en un problema mayor a largo plazo, requiriendo acciones de gestión adicionales, pero hasta la fecha los esfuerzos se han enfocado en la implementación de sitios de nidificación artificiales en Bat Cave para reducir la depredación en los sitios de nidificación menos protegidos. En 2005 y en 2008, dos colonias de cuevas marinas experimentaron mayores eventos de mortalidad adulta, debido a casos inusuales de depredación por parte de zorrillo moteado (Spilogale gracilis amphiala), cuya presencia no había sido registrada con anterioridad. En 2005 en Bat Cave, se capturaron 2 zorrillos después de que estos mataran al menos a 76 adultos. Entre 1995-1997, antes del suceso de mortalidad causado por los zorrillos, esta colonia contaba con 64-97 nidos por año, con bajo éxito reproductivo (49\%-59\%) relacionado principalmente a contaminantes organoclorados. Luego del suceso, los nidos incrementaron de 19 en 2006 a 100 en 2015, con un éxito reproductivo variable pero generalmente elevado (49\%-90\%). En el año 2008, en las cavernas Cavern Point

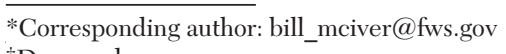

$\dagger$ Deceased 
Cove, se capturaron 2 zorrillos después de que mataran al menos a 32 adultos. Antes del suceso de mortalidad causado por los zorrillos, esta colonia contaba con 11-17 nidos por año entre 1995-1997, con un éxito de reproducción aún menor (20\%-47\%). Los nidos incrementaron de 2 en 2009 a 10 en 2015, con un éxito reproductivo variable pero mayor $(50 \%-80 \%)$. Los casos de depredación por zorrillos pueden deberse a un aumento temporal en su nivel poblacional en SCZ, debido al reducido número de zorros isleños (Urocyon littoralis santacruzae). Los ratones ciervos (Peromyscus maniculatus santacruzae) no fueron depredadores significativos de paíños cenizos en la Isla de Santa Cruz.

Ashy Storm-Petrels (Oceanodroma homochroa; ASSP) are small (38-g) pelagic birds endemic to waters of the California Current System. These seabirds nest on offshore islands and islets from southern Humboldt County, California, to the Coronado Islands off northwestern Baja California, Mexico, and possibly further south (Ainley 1995, Carter et al. 2008, 2015, 2016). Ashy Storm-Petrels generally do not excavate burrows and usually nest in crevices of talus slopes, rock walls, sea caves, cliffs, and driftwood (Ainley et al. 1990, McIver 2002). Nocturnal visitations to colonies, extended periods of parental care, and choice of inconspicuous nesting locations are thought to be adaptations that allow storm-petrel species to avoid most predators (Lack 1968, Warham 1990, McNeil et al. 1993). In addition, ASSP exhibit a long period of adult attendance at colonies before eggs are laid, a clutch size of one, asynchronous egg laying, and long periods of incubation (42-59 d) and parental care of nestlings (72-119 d) (James-Veitch 1970, Ainley et al. 1990, Ainley 1995, McIver 2002).

After the discovery of the 2 largest ASSP colonies at Santa Cruz Island (SCZ) in 1994 (Carter et al. 2018), it became clear that SCZ hosted 2 of only 5 ASSP breeding concentrations in the world of this rare storm-petrel species (Carter et al. 2016). A nest monitoring program was initiated by Humboldt State University in 1995 at 5 colonies (i.e., Cavern Point Cove Caves [CPC], Bat Cave [BC], Orizaba Rock [OR], Cave of the Birds' Eggs $[\mathrm{CBE}]$, and Dry Sandy Beach Cave [DSB]; Fig. 1), each with a sample size of at least 10-15 nests, to determine (1) reproductive success for the first time in the Channel Islands within the southern part of the breeding range and (2) breeding population sizes at these colonies (McIver 2002, Carter et al. 2018). Monitoring of the SCZ colonies occurred from 1995 to 2015 by various entities, including Humboldt State University, the U.S. Fish and Wildlife Service, the National Park Service, the Montrose Settlements Restoration Program, the California Department of Fish and Wildlife,
Carter Biological Consulting, and the California Institute of Environmental Studies. During ASSP nest monitoring at SCZ in 1995-2015, we also quantified predation of storm-petrels at their colonies by carefully recording all evidence of mortalities (e.g., feather piles or carcasses) found during nest monitoring. The purposes of this paper are to (1) describe avian and skunk predation on ASSP at SCZ in 1995-2015, (2) examine colony size and breeding success before and after skunk predation events at BC and CPC, and (3) examine potential management actions pertaining to the predation of ASSP at colonies.

\section{Methods \\ Study Area}

Santa Cruz Island is located $40 \mathrm{~km}$ south of Santa Barbara, California, and is jointly owned and managed by The Nature Conservancy (TNC; west portion) and Channel Islands National Park (CINP; east portion and offshore rocks) (Fig. 1). The island is approximately 39 $\mathrm{km}$ long and $3-11 \mathrm{~km}$ wide. The climate is maritime, with hot, dry summers and cool, wet winters (Crooks 1994). Ashy Storm-Petrels have been documented nesting at 13 locations at SCZ; 11 of these breeding locations occur along the north coast of the island, which is composed of steep cliffs and bluffs where at least 100 sea caves and approximately 20 offshore rocks occur (Bunnell 1988, Carter et al. 2018). The sea caves occur at the bases of cliffs or coastal bluffs and range from about $15 \mathrm{~m}$ to $100 \mathrm{~m}$ in depth (Bunnell 1988). While many caves at SCZ have water bottoms, the floors of the monitored caves (i.e., CPC, BC, $\mathrm{CBE}$, and DSB) generally remain free of standing water throughout most of the year; these 4 caves provide suitable nesting habitat for ASSP in crevices among rock piles, floor cobblestones and driftwood, and along cave walls, either in small cavities or in the open (McIver 2002, McIver et al. 2009). BC and CPC occur within the Scorpion Marine Reserve and CBE occurs within the Painted Cave Conservation 


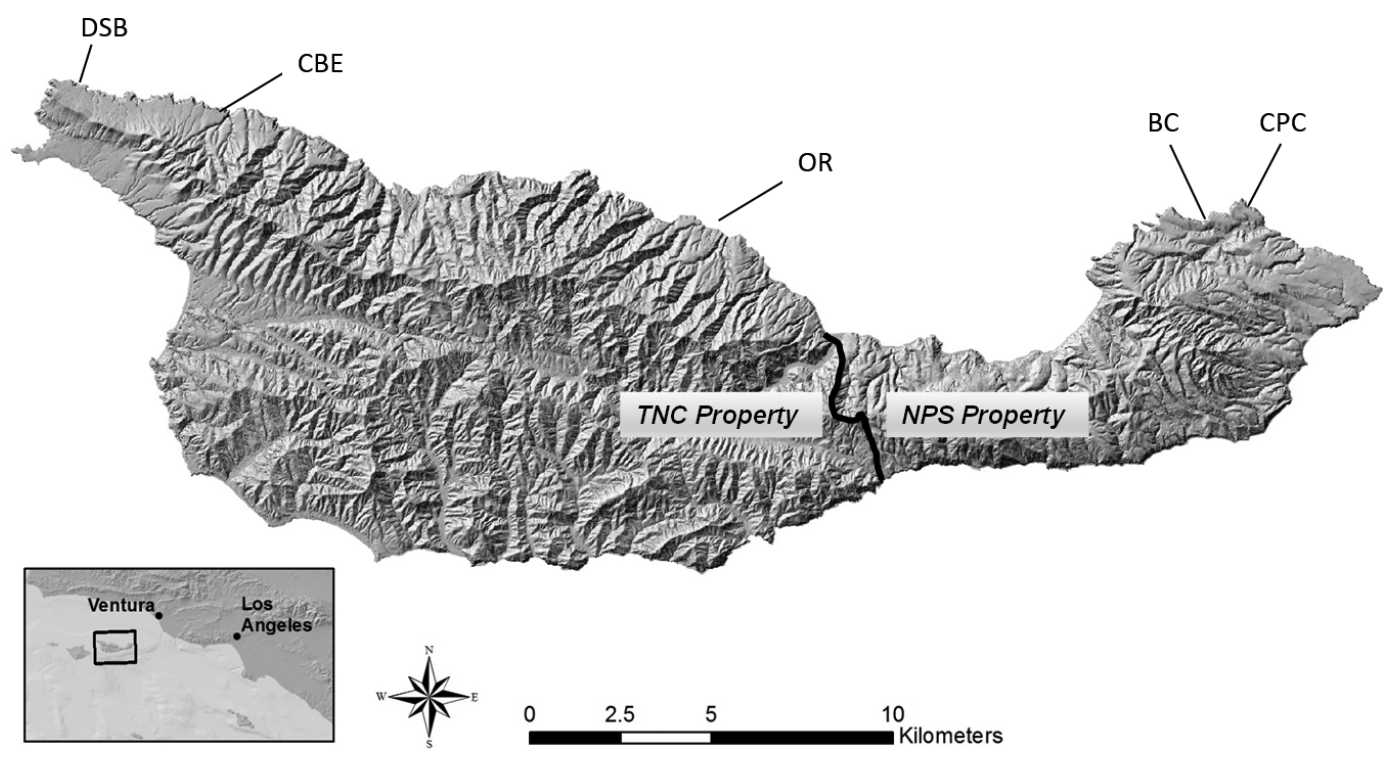

Fig. 1. Locations of Ashy Storm-Petrel colonies at Santa Cruz Island, California: Bat Cave (BC), Cave of the Birds' Eggs (CBE), Cavern Point Cove Caves (CPC), Dry Sandy Beach Cave (DSB), and Orizaba Rock (OR). The current boundary between the National Park Service (NPS) and The Nature Conservancy (TNC) properties is demarcated by the bold black line, but all offshore rocks (including Orizaba Rock) are NPS property also.

Area, both of which were established in 2003 in response to the potential effects of bright lights on ASSP and other seabirds (CDFW et al. 2008). DSB and OR (an offshore rock on the island's north side) are not located in reserve areas. $\mathrm{BC}$ is the second-largest sea cave at SCZ (Bunnell 1988). The main room and primary ASSP nesting area at BC is approximately $30 \mathrm{~m}$ deep with a $15-\mathrm{m}^{2}$ entrance that faces northwest; nests have also been found in side rooms with smaller entrances and under boulders outside and adjacent to the cave. CPC comprises 2 small caves with small entrances (Bunnell 1988).

Three other crevice-nesting seabird species breed at SCZ: Pigeon Guillemot (Cepphus columba), Scripps's Murrelet (Synthliboramphus scrippsi), and Cassin's Auklet (Ptychoramphus aleuticus) (Carter et al. 1992, McIver et al. 2009). These species nest in small numbers with ASSP at the 5 monitored colonies, but ASSP is the most abundant crevice-nesting seabird at these locations. Two primary avian predators of ASSP at SCZ include Barn Owl (BANO; Tyto alba) and Common Raven (CORA; Corvus corax) (McIver 2002, this study). BANO is an uncommon permanent resident and regular breeder at SCZ (Diamond and Jones 1980, Collins and Jones
2015), and CORA is a common permanent resident and regular breeder at SCZ (Collins and Jones 2015). The Western Gull (Larus occidentalis) breeds at SCZ (Carter et al. 1992) and is a known predator of ASSP at Southeast Farallon Island (Ainley et al. 1974, 1990). Western Gulls do not nest in sea caves, however, and only a few ( $<10$ pairs) nest in close association with ASSP at OR (Carter et al. 1992; W.R. McIver and H.R. Carter unpublished data). Newsome et al. (2015) reported that storm-petrel remains were found in nests of Bald Eagles (Haliaeetus leucocephalus) at Santa Catalina Island, California, but we observed eagles infrequently during monitoring at SCZ (McIver and Carter personal observations). ASSP remains have been found in nests of Peregrine Falcons (Falco peregrinus) at San Miguel Island, California (P. Collins unpublished data); we observed falcons occasionally at SCZ (McIver and Carter personal observations). We consider these latter 3 species as potential avian predators at SCZ breeding colonies, although there is no documentation that they prey upon ASSP at these colonies.

Four native species of nonvolant mammals occur on SCZ: the island spotted skunk (Spilogale gracilis amphiala) (Crooks 1994), island fox (Urocyon littoralis santacruzae) (Pergams 
and Ashley 1999), deer mouse (Peromyscus maniculatus santacruzae) (Nelson and Goldman 1931, Pergams and Ashley 1999), and western harvest mouse (Reithrodontymys megalotis) (Pearson 1951). Island foxes and island spotted skunks typically occur in coastal sage scrub and chaparral-grassland habitats on the interior of the island (Crooks 1994). Island spotted skunks were rare and difficult to capture in 1991-1993 (Crooks 1994), but the numbers of skunks increased when island foxes declined on SCZ in the mid-1990s (Crooks and Van Vuren 2000, Bakker et al. 2005, Jones et al. 2008). As fox numbers rise at SCZ, island spotted skunks may again become less common (Coonan and Guglielmino 2012). Deer mice eat a wide variety of foods at SCZ (Murray 1980) and occur in a variety of habitats, including chaparral, rocky outcrops, marshes, riparian zones, pine forests, oak woodland, and buildings and sea caves (Bills 1969, Mayfield et al. 2000, McIver 2002). Western harvest mice occur on the island's interior (Pearson 1951, Bills 1969), not in sea caves or on offshore rocks (McIver 2002). Nonnative rodents such as house mice (Mus musculus) and rats (Rattus sp.) have not been documented at SCZ (Wenner and Johnson 1980, McChesney and Tershey 1998).

\section{Nest Monitoring}

Due to the extended length of the breeding season for each pair, monthly trips in 1995-1998 and 2005-2015 allowed us to effectively measure hatching, fledging, and breeding success and to count the number of nests for determining the annual colony size at the 5 monitored colonies (except DSB, which was monitored monthly during only 7 of those years) (McIver et al. 2016). In the years 1998-2004, single trips in late summer allowed us to obtain the number of active nests present by that time of year (i.e., after most eggs had been laid); this count acted as an index of the annual number of active nests for examining trends in colony size (McIver et al. 2016). Summaries of monitoring have been provided in McIver (2002) and McIver et al. (2009, 2016), and detailed descriptions are found in annual reports prepared for the Montrose Settlements Trustee Council for 2006-2015 (http://www .montroserestoration.noaa.gov/multimedia/ publications/). In general, we searched all accessible habitats at each colony for nests on each visit, using small flashlights, which also enabled us to search all habitats for dead birds. All occupied nest sites were tagged and checked on subsequent visits.

\section{Documentation of Mortalities}

All ASSP feather remains (i.e., a pile of plucked feathers without large bones), whole or partial ASSP carcasses (often sets of wings with a sternum), and owl pellets were described, mapped, and salvaged. In this way all observed ASSP mortalities due to predators were recorded and separated from previous and subsequent mortalities. Feather remains and carcasses were assumed to represent ASSP mortalities caused by avian predators when skunk predation or other factors (e.g., wave wash) were not evident. When skunk predation was evident (i.e., BC in 2005 and CPC in 2008), carcasses and wing sets were assumed to represent mortalities due to skunks and feather remains were assumed to represent ASSP mortalities due to avian predators. For feather remains, the number of storm-petrels killed was estimated by counting feathers according to the type found in the collected samples. Flight feathers included primaries, secondaries, and rectrices; 10-62 flight feathers in a pile represented 1 killed bird. If a sample contained only contour feathers, 100-200 feathers represented 1 killed bird, as in McIver (2002). During years of multiple nest checks (1995-1997 and 2005-2015), feather remains were identified as adult remains if they were collected before the earliest possible fledge date within the year and if no natal down was present. Feather remains collected after the earliest possible fledge date within the year were identified as possible adults or possible fledged chicks. Killed nestling chicks were defined based on the presence of natal down in collected samples. Because it is possible that owl pellets originated from kills also represented by collected feather remains, only feather remains and carcasses were used to determine the number of storm-petrels killed. The presence of avian predators at ASSP colonies at SCZ was confirmed by feather remains, carcasses, pellets, guano streaks, and observation (either directly or with reconnaissance cameras). If not confirmed directly, the avian predator species was assumed to be unknown (but assumed to be either BANO or CORA) and assessed indirectly by available 
evidence, such as owl pellets or photographs from cameras. Depredated eggs were not included in ASSP mortalities. All mortalities were tallied for each year, and totals represented the minimum number of storm-petrels killed. Some individuals may have been removed from colonies or killed away from colonies by avian predators or taken to inaccessible locations within colonies by skunks. However, the abundant evidence of predation found at colonies suggested that most predators consumed storm-petrels at the colonies where the predation occurred.

\section{Reconnaissance Cameras}

Reconnaissance cameras (HC500 HyperFire $^{\mathrm{TM}}$, RECONYX Inc., Holmen, WI, USA) were deployed at OR (1-3 cameras/year) in 2010-2015 and BC (1-4 cameras/year) in 2013-2015 to detect CORA visiting these colonies. Pictures were taken when a camera was motion-activated within the field of view during the day or night; cameras were programmed to take 3 photographs within 3 consecutive seconds before resetting. Memory cards and batteries in the cameras were changed during monitoring trips. Images on memory cards were reviewed on a computer. For any avian predator observed in the images, we recorded the date, time duration (to the nearest second), number of pictures taken during "visitations," specific reconnaissance camera used, and numbers and behavior of birds. Camera data were archived at CINP.

\section{Skunk Trapping}

When skunks were detected, traps (Havahart ${ }^{\circledR}$ live traps, Woodstream Corporation, Lititz, PA, USA) were deployed at BC (11-12 June 2005) and CPC (June-October 2008) to prevent further predation upon ASSP. Each trap was baited with a partly opened can of wet cat food to attract skunks. At CPC in 2008, specific skunk-trapping trip dates were 19-20 June, 22 June, 24 June, and 3 July; traps were subsequently checked and rebaited with cat food on monthly nest monitoring trips.

To prevent ASSP predation by skunks before they were detected, lethal body-grip skunk traps $\left(220\right.$ Conibear ${ }^{\circledR}$ trap, Oneida Victor Inc. Ltd., Euclid, OH, USA) were deployed at BC, CBE, and CPC in 2009-2014; traps were not deployed at DSB or OR. Traps were set inside protective wooden boxes (approximate box dimensions: $19 \mathrm{~cm} \times 19 \mathrm{~cm} \times 50 \mathrm{~cm})$. When open and armed, the jaw-spread of each trap measured approximately $18 \mathrm{~cm}$ (7 inches). The inside of each box was wide enough to allow the insertion and deployment of a trap but minimized space around the edges of each trap in order to direct skunks to the trap opening and wire trigger. Stiff wire mesh screening was stapled on both ends of each protective box to prevent entry by crevicenesting seabirds; screening on one end allowed entry by skunks only. Each box was baited with a partly opened can of wet cat food placed on the opposite side of the trap from the swinging mesh door. Trap boxes were placed near the entrances of caves to try to capture skunks prior to their entering the caves and depredating any storm-petrels. Boxes were partly covered with rocks to secure and hide them, and traps were secured to the ground with metal stakes. After deployment, trap boxes were examined on each field trip to check for any trapped skunks, to ensure proper functioning of traps and boxes, and to replace bait. Traps, protective boxes, and bait were removed from the sea caves in autumn of each deployment year and redeployed the following spring. Skunk traps were not deployed in 2015 due to reported low numbers of skunks on SCZ and no skunk predation events in the sea caves after 2008 (this study).

\section{Colony Sizes and Reproductive Success}

To assess the degree of ASSP mortality caused by skunks and the rate of colony recovery following skunk predation events, we examined 3 colony parameters at $\mathrm{BC}$ and CPC between 1995 and 2015, including colony size (i.e., the number of active nests per year), colony size index (i.e., the number of active nests in late summer, usually over $80 \%-90 \%$ of the annual total), and breeding success (i.e., the percentage of nest sites that fledged a chick, using a single egg or replacement eggs). To examine trends in the colony size index, simple linear regressions of logtransformed numbers of active nests in late summer at BC and CPC were conducted using the following data: (1) 1995-2004 (pre-skunk predation period using July counts, except in 1998 [August count] and 2004 [June count]) and 2006-2015 (post-skunk predation period using July counts) at BC and (2) 1995-2007 (pre-skunk predation period using July counts, 
except in 1998 [August count] and 2004 [June count]) and 2009-2015 (post-skunk predation period using July counts) at CPC. In addition we compared trends at $\mathrm{BC}$ and $\mathrm{CPC}$ with CBE (1995-2014 July counts and the August 2015 count), which did not experience skunk predation and thus served as a reference colony. In 1995-1997 and 2005-2015, nest sites from which a fresh egg or an eggshell fragment was removed for trend analyses by researchers prior to the July or August monitoring trip were treated as active nests that would have been counted in July or August. All data were subjected to assessments of normality and equal variance before statistical analyses (ANOVAs) were performed. Normality was assessed with histograms and the Shapiro-Wilk normality test $(P<0.05)$. Equal variances were assessed using Levene's test with significance at $P<0.05$. Normally distributed data with equal variances were analyzed using parametric analyses. Nonnormal data were analyzed using nonparametric analyses. For all linear regressions the assumption of normality of residuals was assessed using quantile-quantile plots to visually assess normality; the assumption of homogeneity of variance was assessed using plots of residuals versus fitted values.

\section{Results}

\section{Avian Predation}

We estimated that a minimum of 295 ASSP were killed by avian predators at SCZ over the entire study period (1995-2015); percentages of kills by location are as follows: $79.3 \%$ at $\mathrm{BC}, 10.5 \%$ at $\mathrm{OR}, 7.1 \%$ at $\mathrm{CBE}, 2.0 \%$ at CPC, and $1.0 \%$ at DSB (Table 1). In years of multiple nest monitoring trips (1995-1997 and 2005-2015), a minimum of 248 ASSP were killed by avian predators: 210 ASSP adults, 34 birds of undetermined age (adults or fully fledged chicks), and 4 nestling chicks (Table 1). Avian predation accounted for $71.4 \%$ of 413 total predation events detected at SCZ over the entire 1995-2015 study period $(n=413)$ (Table 1). Two major periods of predation at BC were noted: (1) 75 ASSP killed in 1995-1997 represented $32.1 \%(n=234)$ of $\mathrm{BC}$ avian mortalities in 1995-2015 and $25.4 \%(n=295)$ of all avian mortalities in 1995-2015 and (2) 104 ASSP killed in 2013-2015 represented $44.4 \%$ of BC avian mortalities in 1995-2015 


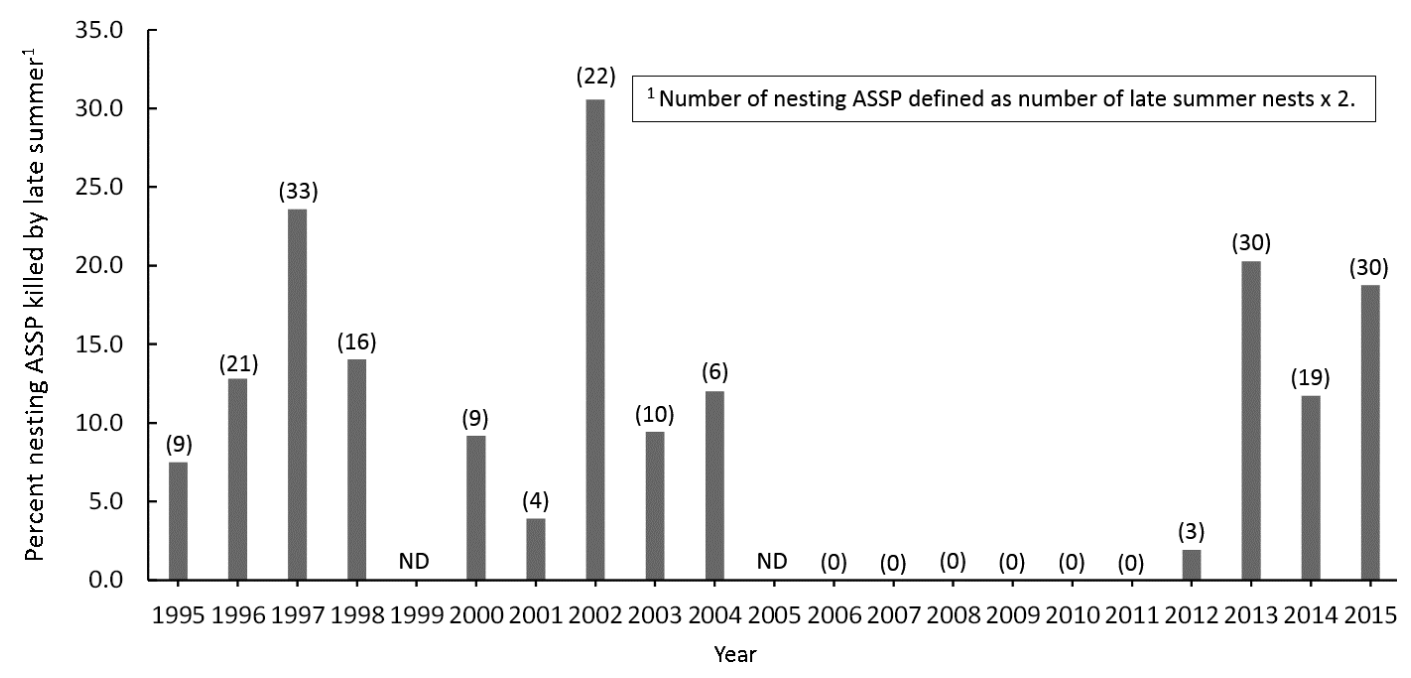

Fig. 2. Percentage of nesting Ashy Storm-Petrels killed by avian predators by late summer at Bat Cave, Santa Cruz Island, California, in 1995-2015. ND = no data; the colony was not visited in 1999 and a major skunk predation event occurred in 2005. The counts of adult Ashy Storm-Petrels killed by late summer are shown in parentheses above the bars.

and $35.3 \%$ of all avian mortalities in 1995-2015 (Table 1). Late-summer predation by CORA in 2013-2015 $(n=79)$ was greater than latesummer avian predation observed in any other consecutive 3-year period, although relatively high avian predation $(n=63)$ also occurred in 1995-1997 (Fig. 2).

Avian predators were detected in more years at $\mathrm{BC}(75 \% ; n=20)$ and $\mathrm{OR}(74 \% ; n=$ $19)$ than at $\mathrm{CBE}(40 \% ; n=20)$, CPC $(22 \% ; n$ $=18)$, and DSB $(17 \% ; n=18)$ (Table 2). Specific species of avian predators at storm-petrel colonies were confirmed by direct observation (i.e., 1 BANO roosting in $\mathrm{BC}$ on 18 September 1996 and 1 CORA roosting in CBE on 18 June 1997), images captured by reconnaissance cameras (CORA at OR in 2010-2015 and BC in 2013-2015), the discovery of owl pellets (at $\mathrm{BC}, \mathrm{CPC}$, and $\mathrm{OR}$ in numerous years), and the discovery of raven feathers (at $\mathrm{BC}$ in 1997, DSB in 2002, and OR in 2006). BANO presence was confirmed at $\mathrm{BC}, \mathrm{CPC}$, and $\mathrm{OR}$. CORA presence was confirmed at $\mathrm{BC}, \mathrm{CBE}$, DSB, and OR. After skunk predation events, avian predation was much reduced or absent for 7 years (2006-2012) at BC until it increased again in 2013-2015 (Table 1). Common Ravens were observed annually in images from reconnaissance cameras at BC (2013-2015) and OR (2010-2015) (Table 3); no owls were observed in camera images. Cameras detected predation on 1 egg, 1 chick, 4 adult ASSP, and 2 unidentified downy seabird chicks (auklet or storm-petrel); no more than 3 ravens were observed in any 1 image (Table 4, Fig. 3). Based on time and date stamps of images, ravens were observed on the same day at both OR and BC on 21 different days in 2014; $33 \%$ of these observations occurred within $1 \mathrm{~h}$ of an observation from the other location. In a review of field notes prior to 2005 (McIver and Carter unpublished notes), we found the following references to ravens: 1 raven feather was found in BC on 19 August 1997 and raven footprints in the sand and raven feathers "throughout [the] cave" were found at DSB on 18 August 2002.

\section{Skunk Predation}

Bat Cave.-From 2 June 2005 to 15 September 2005, predation of at least 89 ASSP by at least 2 island spotted skunks was documented in the main room and side chambers of $\mathrm{BC}$ and in crevices among boulders outside of the cave (Table 1). Neither active nests nor eggshells were found on 2 June 2005, but 73 carcasses were discovered. Salvaged ASSP carcasses were examined and found to have missing heads, puncture wounds in the backs of skulls, or wing-sets without bodies. One skunk was live-trapped and removed from BC on 11 June 2005. On 28 July 2005, we recorded 15 active storm-petrel nests (bird on egg or egg only $[n=10]$, adult bird "sit in 
TABLE 3. Numbers of days that reconnaissance cameras were deployed and Common Ravens (CORA) were observed in camera photographs at Orizaba Rock and Bat Cavea , Santa Cruz Island, California.

\begin{tabular}{lcc}
\hline Year & $\begin{array}{c}\text { Number of days } \\
\text { cameras deployed }\end{array}$ & $\begin{array}{c}\text { Number of days } \\
\text { CORA observed }\end{array}$ \\
\hline 2010 & 63 & 1 \\
2011 & 291 & 48 \\
$2012^{\mathrm{b}}$ & 221 & 7 \\
2013 & $319 / 205$ & $31 / 32$ \\
2014 & $298 / 342$ & $84 / 105$ \\
2015 & $365 / 267$ & $111 / 122$
\end{tabular}

$\overline{\text { aCameras were deployed at Bat Cave in 2013-2015 only; values after slash (/) }}$ marks.

bonly 1 camera was deployed at Orizaba Rock in 2012.

TABle 4. Observations of Common Ravens (CORA) that show or suggest predation upon Ashy Storm-Petrels (ASSP), as seen in pictures from reconnaissance cameras deployed at Bat Cave and Orizaba Rock, Santa Cruz Island, California.

\begin{tabular}{|c|c|}
\hline Location/date & Observation \\
\hline \multicolumn{2}{|l|}{ Bat Cave } \\
\hline 14 Jun 2013 & 1 CORA w/ 1 adult ASSP in bill \\
\hline $23 \mathrm{Jul} 2013$ & $\begin{array}{l}3 \text { CORA investigating driftwood } \\
\text { (and ASSP nesting) area of cave }\end{array}$ \\
\hline 23 Jun 2015 & 1 CORA w/ 1 adult ASSP in bill \\
\hline $1 \mathrm{Jul} 2015$ & 1 CORA w/ 1 adult ASSP in bill \\
\hline 9 Aug 2015 & 1 CORA w/1 ASSP egg in bill \\
\hline \multicolumn{2}{|l|}{ Orizaba Rock } \\
\hline 14 Nov 2010 & $\begin{array}{l}\text { 1 CORA looking into artificial nest } \\
\text { site }\end{array}$ \\
\hline 30 Apr 2014 & $\begin{array}{l}1 \text { CORA w/ unidentified chick } \\
\text { (ASSP or CAAU) in talons }\end{array}$ \\
\hline 7 Aug 2014 & 1 CORA w/ASSP chick in bill \\
\hline 24 Jan 2015 & 1 CORA w/ 1 adult ASSP in bill \\
\hline 19 Mar 2015 & $\begin{array}{l}1 \text { CORA w/unidentified prey item } \\
\text { (ASSP or CAAU) in bill }\end{array}$ \\
\hline 6 Nov 2015 & $\begin{array}{l}2 \text { CORA poking bills into } 2 \text { artificial } \\
\text { nest modules }\end{array}$ \\
\hline
\end{tabular}

nest" $[n=3]$, and chick only $[n=2])$. On 15 September 2005, however, no active nests remained and 16 more ASSP carcasses (15 adults and 1 chick)—some with similar puncture wounds-were found, indicating additional predation by at least one more skunk (Table 1). We observed evidence of digging in the hard-packed dirt of the cave floors at many locations within the cave. In 2005 we did not attempt to trap skunks after 11 June 2005 and did not observe ASSP nesting attempts after 15 September 2005. In late March 2006, trained trappers from CINP visited BC prior to egg laying to live-trap any skunks that may have remained in or accessed the cave over the winter; neither skunks nor dead storm-petrels were observed. No skunks were 

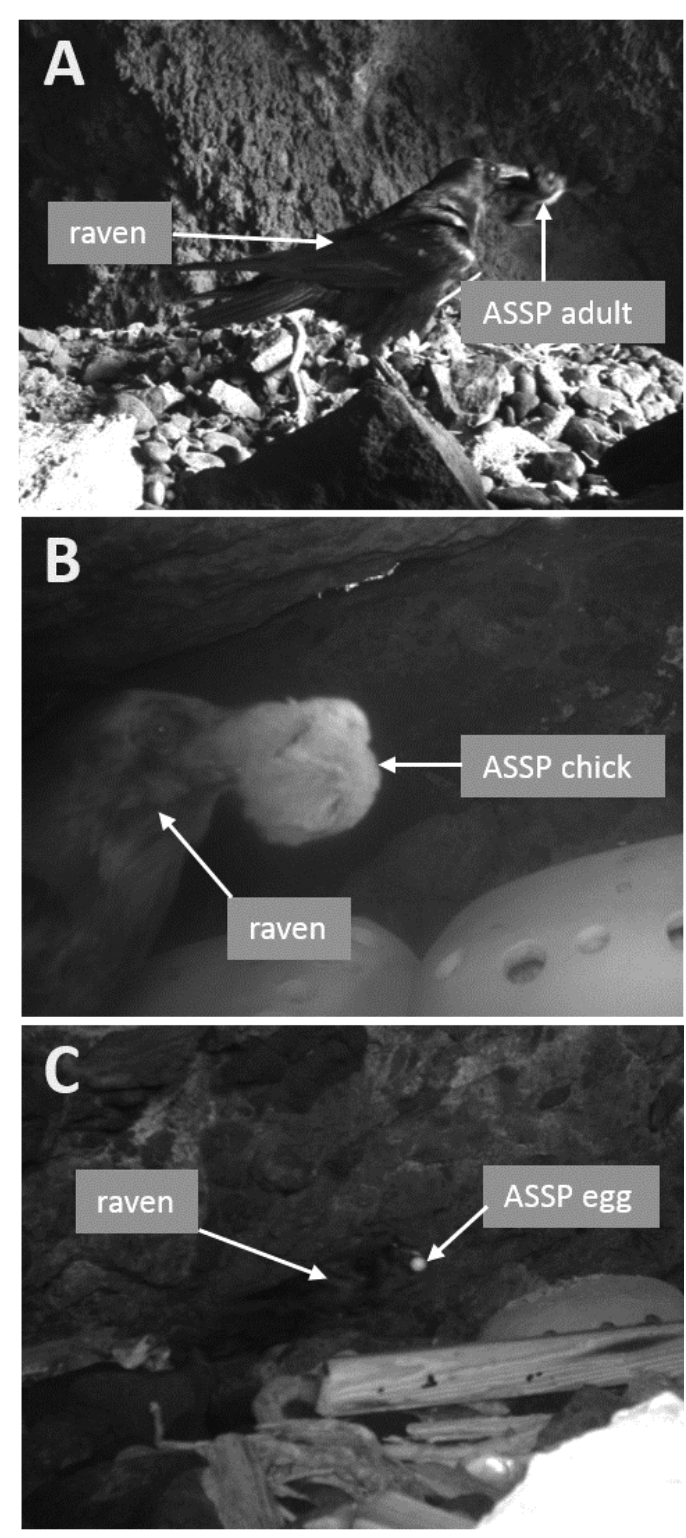

Fig. 3. Reconnaissance camera images from Santa Cruz Island, California, showing Common Raven predation of Ashy Storm-Petrels (ASSP): A, adult at Bat Cave, 14 June 2013; B, chick at Orizaba Rock, 7 August 2014; C, egg at Bat Cave, 9 August 2015. Images from original pictures were enlarged slightly and corrected to enhance brightness.

detected at $\mathrm{BC}$ during preventative trapping efforts in 2009-2014, and skunk odor at BC was not detected after 2005.

Cavern Point Cove Caves.-On 28 April 2008 during the deployment of artificial nest sites at CPC, we observed 12 active nests in "Cave \#4" $(n=4)$ and "Cave \#5" $(n=8)$.
From 16 June 2008 to 9 September 2008, predation of at least 29 ASSP by at least 2 island spotted skunks was documented at CPC (Table 1). As found at BC, ASSP carcasses were examined and found to have missing heads or puncture wounds in the backs of skulls. On 16 June 2008, we detected skunk odor and evidence of digging within the caves, along with at least one skunk "latrine area" containing approximately 50 individual scats. On 3 July 2008, one skunk was live-trapped, removed from CPC, and subsequently released near Smuggler's Cove approximately $4 \mathrm{~km}$ away. Skunks were not detected at CPC during preventative trapping efforts in 2009-2014, and skunk odor was not detected at CPC after 2008. Skunks were not detected at CBE during preventative trapping efforts in 2009-2014, nor was skunk odor detected there.

\section{Trends in Colony Size Index}

Over the entire study period (1995-2015), numbers of ASSP nests in late summer increased by $8.1 \%$ per annum $(P<0.001)$ at the reference colony at $\mathrm{CBE}$ (Table 5, Fig. 4C). Nest numbers were similar in 1995-1998 $(n=8-10)$, dipped in 1999-2000 $(n=3-5)$, returned to previous levels in 2001-2002 $(n=9$ each year), increased in 2004-2009 $(n=13-26)$, decreased slightly in 2010-2011 $(n=18$ each year), and returned to 2007-2009 levels in 2012-2015 $(n=22-26)$.

Before skunk predation at BC in 2005, nest numbers decreased $8.5 \%$ per annum from 1995 to $2004(P=0.007)$; after skunk predation, nest numbers increased $17.7 \%$ per annum $(P<0.001)$ from 2006 to 2015 (Table 5, Fig. 4A). At CPC before skunk predation in 2008 , nest numbers did not change significantly from 1995 to 2007 ( $P=0.972$ ); after skunk predation, nest numbers increased $42.6 \%$ per annum $(P=0.004)$ from 2006 to 2015 (Table 5, Fig. 4B).

\section{Breeding Success}

Breeding success at SCZ (all 5 monitored colonies combined) averaged 54.9\% in 1995-1998 and $62.7 \%$ in 2005-2015 (Table 6). At BC, $\mathrm{CBE}$, and CPC combined, breeding success averaged $50.7 \%(n=284)$ in $1995-1998$ and $67.0 \%(n=906)$ in 2005-2015 (Table 6). Overall breeding success at SCZ in $2015(49 \%, n=$ 138) was the second lowest observed since $1996(45 \%, n=173)$ and was significantly 


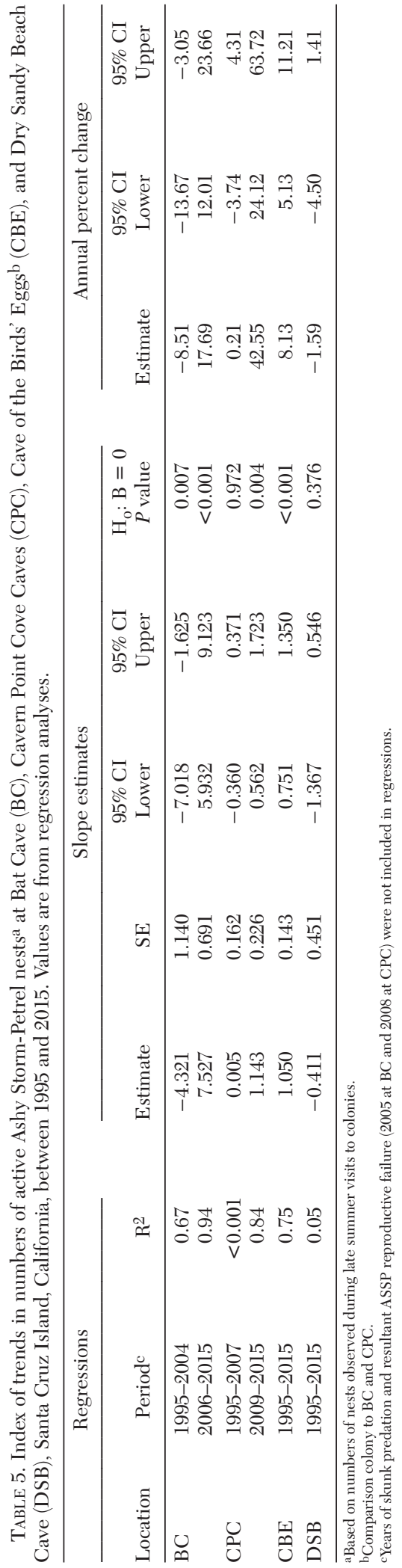

lower than the long-term average for SCZ in 2005-2015 (63\%, $n=1267)$ (Table 6). The third lowest $(53 \%, n=155)$ and fourth lowest $(54 \%, n=124)$ breeding success values at SCZ occurred in 2013 and 1995, respectively.

\section{Discussion}

Avian Predation

At Santa Cruz Island, Barn Owls and ravens killed at least 295 ASSP from 1995 to 2015 , and avian predation was documented at a sea cave colony or at Orizaba Rock in every year except 1998. We observed (through use of reconnaissance cameras) 5 instances of ravens depredating ASSP (4 adults and 1 chick; Table 4, Fig. 3) and 2 instances of ravens depredating downy chicks (Cassin's Auklet or ASSP); otherwise, attributing a feather pile to a particular avian predator (owl or raven) was based on circumstantial evidence, such as direct observation of predators at colonies, ravens in reconnaissance camera images, owl pellets found at colonies, or raven feathers found at colonies. Similarly, at Fish Island, Alaska, Quinlan (1983) attributed 65 remains of Fork-tailed Storm-Petrel (O. furcata) to 3 avian predators (Bald Eagle, Common Raven, and Peregrine Falcon) based on indirect observations of these species at the storm-petrel colony and storm-petrel remains near predator nests or feeding sites; however, she did not quantify and attribute individual storm-petrel feather piles to specific avian predators. In contrast, at Benidorm Island, Spain, Oro et al. (2005) determined that Yellow-legged Gulls (L. michahellis) were predators of European Storm-Petrels (Hydrobates pelagicus), based on storm-petrel tibias (some with identification bands) recovered from regurgitated gull pellets.

BARN OwL. Barn Owls have been reported at SCZ since the early 20th century (Howell and van Rossem 1911), but the species has likely occurred there for thousands of years, judging from prehistoric fossils (dated to approximately $7300 \mathrm{BP}$; P. Collins personal communication) at San Miguel Island, $35 \mathrm{~km}$ west of SCZ (Guthrie 1993). We suspect that the BANO was the primary avian predator of ASSP at SCZ in 1995-1997 (McIver 2002) based on (1) the presence of feather remains and other contents of 13 owl pellets at BC $(n=9)$ and OR $(n=4), 11$ of which contained 

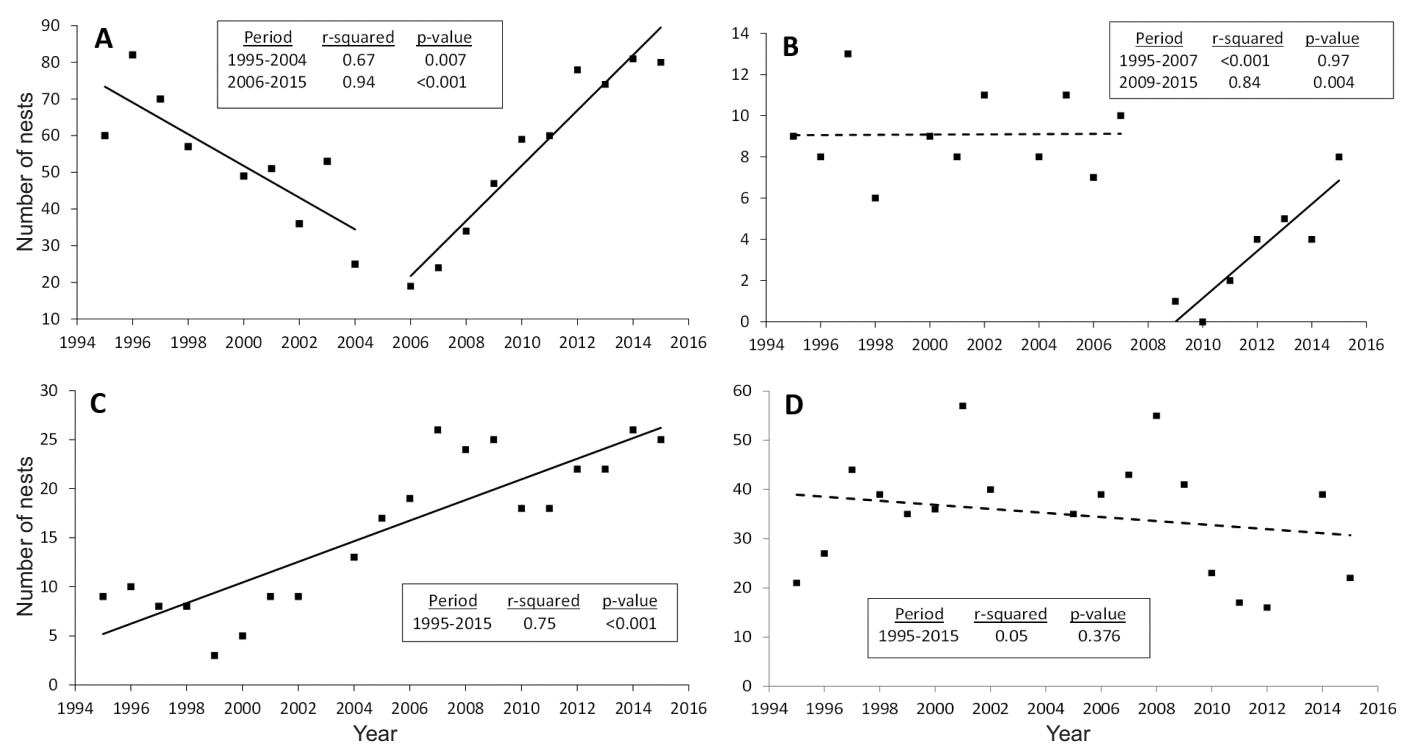

Fig. 4. Trends in active nest numbers of Ashy Storm-Petrels at Santa Cruz Island, California, in 1995-2015: A, Bat Cave; B, Cavern Point Cove Caves; C, Cave of the Birds' Eggs; D, Dry Sandy Beach Cave. Years of skunk predation events (2005 at Bat Cave and 2008 at Cavern Point Cove Caves) were not included; hence the 2 trend lines for each of these locations.

ASSP feathers and bones; (2) the documented use of 2 perches by BANO at BC, including excrement and pellets beneath; (3) a daytime observation of a BANO roosting in BC on 18 September 1996; and (4) nocturnal observations (during mist-netting) of BANO at OR (also see Carter et al. 2018). In 2002 and 2004, we found BANO pellets with stormpetrel remains at $\mathrm{BC}$ and $\mathrm{OR}, \mathrm{BANO}$ roost sites at BC, and a Cassin's Auklet (Ptychoramphus aleuticus) carcass at $\mathrm{OR}$ - probably killed by a BANO — without a head and with a chewed sternum. During 2005-2015, predation of ASSP by BANO appeared to be much reduced at SCZ, particularly at BC after the major skunk predation event and thus reduced numbers of ASSP. While 4 feather piles found in $\mathrm{BC}$ in 2005 were attributed to BANO, the majority of feather piles and carcasses appeared to be predation by island spotted skunks. In 2006-2011, no feather piles were found at $\mathrm{BC}$, which suggested that BANO were hunting elsewhere. Evidence of BANO was noted at BC in April 2010, however, when a pellet (with ASSP bones, feathers, and 2 skulls) was discovered, but no ASSP feather piles were found at this time, suggesting that ASSP were killed elsewhere and brought to $\mathrm{BC}$ or that ASSP killed at BC were taken elsewhere to be consumed. In October 2012, 2 ASSP feather piles (BANO or CORA) were found in BC. In 2013, one BANO pellet was found in $\mathrm{BC}$, although predation by CORA was prevalent (see "Common Raven" section below).

Ashy Storm-Petrels arrive at and depart from nesting colonies at night in order to avoid diurnal avian predators (Ainley 1995). Barn Owls hunt mostly at night, but occasionally hunt diurnally; most hunting is done by low flight above the ground in open habitats, but some hunting is done from perches (Bunn et al. 1982, Lenton 1984, Marti 1992). Ashy Storm-Petrels often socialize on the ground outside of nest sites prior to incubation, increasing their vulnerability to predation by BANO (James-Veitch 1970). After an egg is laid, most adult socializing ceases and mates alternate incubation bouts and later share chick-feeding duties; at this time, adults are less frequently present on the surface and are therefore less vulnerable to BANO predation (James-Veitch 1970). Ashy Storm-Petrels typically remain silent at a nest site, although some vocalizing occurs (W. McIver personal observation). In SCZ sea caves, most ASSP nests $(77 \%)$ are in shallow crevices (i.e., <30 $\mathrm{cm}$ from the entrance to an egg or a bird) and some are in open locations (McIver 2002), 


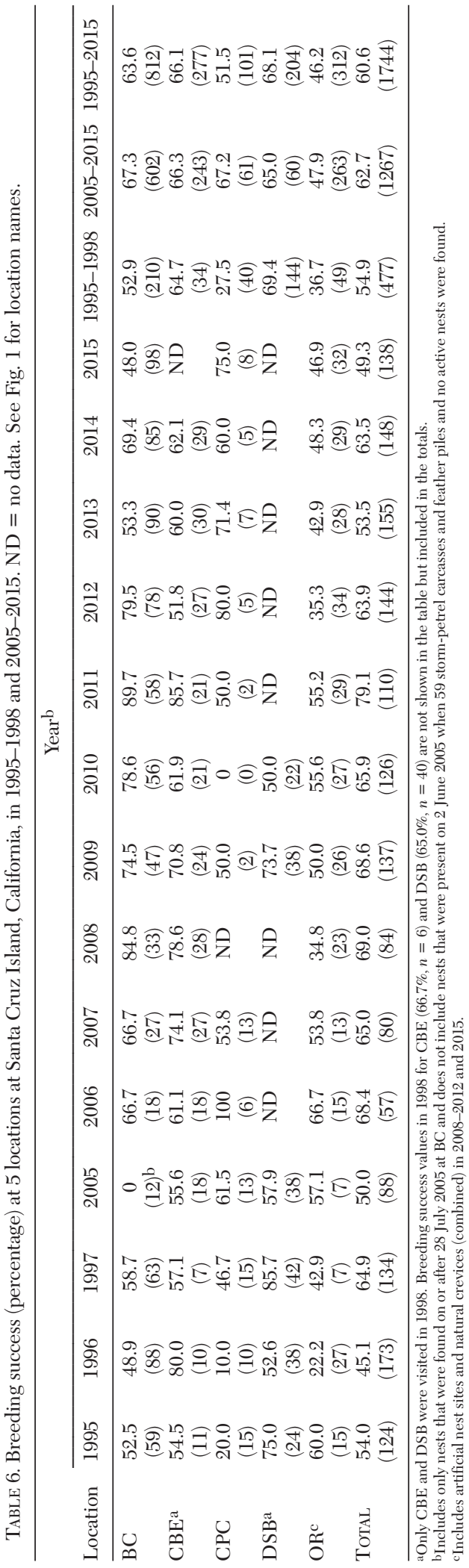

exposing nesting adults to predation by BANO. Subadult ASSP that engage in social behaviors aboveground in sea caves at night would be vulnerable to BANO predation. We usually could not distinguish between adults and subadults in feather piles and carcasses but suspect that both subadults and adults were killed.

COMMON RAVEN. Impacts on artificial ASSP nests at OR were first noted in 2010, leading to the deployment of reconnaissance cameras to identify the culprits, which turned out to be CORA (McIver et al. 2016). Modifications to artificial nests in 2011-2013 eventually prevented CORA impacts at artificial sites by 2014-2015, but heightened predation (3-9 ASSP/year) was also noted at OR in 2012-2015. In 2013, heightened predation also began at $\mathrm{BC}$, followed by the deployment of cameras to identify predators. In 2013-2015, multiple CORA (as many as 3 ravens in a set of pictures) were documented actively patrolling the driftwood pile where at least $25 \%$ of ASSP nests at BC occur. Based on camera data, CORA were responsible for extensive predation of ASSP at BC in 2013 (45 feather piles), 2014 (22 feather piles), and 2015 (44 feather piles).

In 2015 a CORA pair at OR was recorded on camera working in tandem and inspecting the artificial nest modules with their bills, suggestive of "cooperative hunting," as reported in the Brown-necked Raven (Corvus ruficollis) (Yosef and Yosef 2010). For Leach's StormPetrel on Bon Portage Island, Nova Scotia, American Crows (C. brachyrhynchos) and CORA were major predators of adults and the second greatest cause of chick mortality (MacKinnon 1988). These corvids were frequently observed walking throughout the storm-petrel colony, apparently locating stormpetrel chicks by their vocalizations in nesting burrows and then excavating burrows to kill and eat adults and chicks. Similarly, on Daikoku Island, Japan, Large-billed Crows $(C$. macrorhynchos) excavated a small number of Leach's Storm-Petrel burrows (Watanuki 1985). Ashy Storm-Petrels nesting in shallow and accessible nest sites at $\mathrm{BC}$ and $\mathrm{OR}$ are defenseless against a diurnal predator as large, intelligent, and persistent as a CORA. In addition, ASSP adults, chicks, and eggs inside and outside of nest sites are vulnerable to CORA predation, whereas BANO only prey on birds 
(adults and mobile chicks) outside of nest sites at night (see "Barn Owl" section above). A greater proportion of ASSP at BC and OR are vulnerable to predation by CORA compared to BANO. The higher level of CORA predation may not be sustainable over time, potentially leading to significantly reduced numbers of nests in natural nest sites at BC and OR. Nest numbers at BC and OR had not declined by 2015 , but these colonies are still recovering from past impacts by skunks (BC) and bright lights from squid fishing boats (OR; see McIver et al. 2016), potentially masking impacts from CORA to date. Artificial nest sites and natural nests in deep crevices are protected from CORA predation, however, so breeding is likely to continue at these locations with lower population sizes.

From 1992 to 2000 (but especially from 1995 to 1997), intense market squid (Doryteuthis opalescens) harvesting at SCZ occurred by use of bright lights at night. This harvest apparently caused a large decline in nest numbers at OR from 1995 to 2004, with the largest drop in nest numbers occurring between 1996 and 1997 (Maxwell et al. 2004, McIver et al. 2016). Nesting areas at CBE were less exposed to squid fishing lights than at OR because most nests at CBE occur over $20 \mathrm{~m}$ inside the westfacing cave entrance, away from squid fishing areas off the north side of SCZ (McIver et al. 2016). With lower impacts, the numbers of nests at CBE declined less, with the largest drop between 1998 and 1999, and showed a rapid recovery after 1999 (Fig. 4C). Due to the large northwest-facing entrance at $\mathrm{BC}$, nesting areas in the shallower main room were likely more exposed to squid fishing lights off the north side of SCZ than nesting areas at CBE; however, many parts of the extensive cave network at $\mathrm{BC}$ were not as exposed. Decreases in nest numbers at BC occurred mainly between 1996 and 2000 (though lower nest numbers in 1995 may have reflected less intense nest searches than in 1996), with little recovery by 2005 when the skunk predation event occurred (Fig. 4A). We consider that some impacts from squid fishing lights (e.g., nest/colony abandonment, reduced recruitment, or predation) occurred at BC in 1995-2000, but such impacts were likely reduced by squid fishing regulations and reduced fishing efforts after 1997 and stopped altogether in 2003 with the establishment of the Scorpion Marine Reserve that prohibited squid fishing near this colony. Reduced nest numbers were not evident at nearby CPC in 1995-2004 (Table 5, Fig. 4B) because the entrances to these small caves face to the northeast with less penetration of light into caves. Similarly, decreased nest numbers were not evident at DSB (Table 5, Fig. 4D) where nesting areas occur $>40 \mathrm{~m}$ within the cave. However, crevice nesting habitat within DSB may be susceptible to wave-wash events during the breeding season (W. McIver personal observation).

We could not identify individual CORA at $\mathrm{BC}$ and $\mathrm{OR}$ (i.e., none were banded or marked). However, the presence of one "begging" juvenile with the 2 adults at $\mathrm{BC}$ on 24 June 2014 (J. Howard personal observation) suggested that some adults obtain prey for their young at BC. Common Raven egg-laying dates vary considerably between mid-February and late May; juveniles become independent by July or August (Boarman and Heinrich 1999). Learning in CORA can be specifically influenced by observing an experienced conspecific (Fritz and Kotrschal 1999). If foraging in a storm-petrel colony is learned at SCZ, we should expect continued impacts of CORA on storm-petrels that nest in shallow crevices and open sites.

One CORA was observed inside CBE during a nest check in 1997; we attributed the death of 1 Pigeon Guillemot chick to predation by CORA because the chick was dragged from a nest site and peck marks were evident on the carcass (McIver 2002). Other evidence of ravens was also found at BC in 1997 and DSB in 2002, prior to 2010-2015 when raven presence and predation at $\mathrm{OR}$ and $\mathrm{BC}$ increased. While the possibility of raven predation of ASSP in 1995-1997 could not be discounted, McIver (2002) considered ravens to be uncommon in sea caves at that time, so some predation events attributed to Barn Owls may have been caused by ravens. Over the 1995-2015 period, raven predation events in late summer in 2013-2015 $(n=79)$ were greater than in any other consecutive 3-year period (e.g., 1995-1997: $n=63$ ).

Common Ravens are generalist commensal omnivores that benefit from resource subsidies provided by human activities (Boarman et al. 2006); these corvids eat live meat, eggs, insects, grains, fruit, garbage, and carrion (Boarman and Heinrich 1999), all of which are 
available to CORA at SCZ. The main food source on the island from the mid-19th century to the late 20th century was dead livestock, especially sheep (Blake 1887, Schuyler 1993). Although livestock were removed in the 1980s and 1990s, a major campground was developed by CINP in 1997 at Scorpion Ranch near BC and CPC. Common Ravens are highly intelligent and can quickly adapt to the presence of humans, often developing specialized feeding behaviors (Liebezeit and George 2003, Marzluff and Angell 2005). Food may be the most important anthropogenic resource driving the increase in corvids near settlements and campgrounds (Marzluff and Neatherlin 2006). Ravens are known to be adept at obtaining food from campgrounds, including using techniques such as opening gate latches, backpack zippers, and food containers (Janiskee 2010; D. Mazurkiewicz personal observation), and those nesting in close proximity to anthropogenic food resources have increased juvenile survival (Webb et al. 2004).

Predation of Pigeon Guillemots by Northwestern Crows (Corvus caurinus) may have been related to crows following researchers (Vermeer et al. 1993). Researchers visited ASSP breeding locations at SCZ monthly in 1995-1997 and 2005-2012, often without noting CORA (exceptions: CBE in 1997 and DSB in 2002). In 2014-2015, cameras were deployed during the entire breeding season to assess possible CORA attraction to researchers. Dates on which ravens were observed (by camera) and dates of nest monitoring at BC and OR $(n=29)$ coincided on 3 dates (26 May 2015, 17 June 2015, and 26 August 2015 at $\mathrm{BC})$, but only on the last date were ravens photographed by cameras after nest monitoring. Though ravens apparently were aware of our activities, they mainly visited BC subsequent to monitoring; a direct correlation between the presence of ravens and nest monitoring was not apparent. The infrequent detection of ravens during nest monitoring may have reflected (1) a process of learning by ravens that likely involved investigating vocalization broadcasting at OR in 2008-2012 and watching researchers entering and exiting $\mathrm{OR}$ and $\mathrm{BC}$ and (2) raven avoidance of $\mathrm{OR}$ and $\mathrm{BC}$ during monitoring visits but regular occurrence at these locations between our visits.
Blake (1887) described ravens at SCZ as "very common." We are not aware of recent population estimates of ravens at SCZ, but approximately 50-100 roosting birds were observed on the east end of the island near Scorpion Ranch during one afternoon in summer 1997, prior to campground development (McIver personal observation). Because only 1-3 ravens were observed in specific images taken by the reconnaissance cameras, it seems that only a few ravens may be visiting $\mathrm{OR}$ and $\mathrm{BC}$ at a time. Based on time and date stamps of camera images in 2014, ravens were observed on the same day at both OR and BC ( 14 km apart) on 21 different days; 33\% of these observations occurred within $1 \mathrm{~h}$ of an observation at the other location. In coastal California, the median home range of nesting ravens was about $1.2 \mathrm{~km}^{2}$ (range $0.3-4.4 \mathrm{~km}^{2}$, $n=12$ ) versus $8.2 \mathrm{~km}^{2}$ (range $2.2-45.8 \mathrm{~km}^{2}$, $n=5$ ) for nonnesting birds (Linz et al. 1992). Different individual ravens likely visit OR and $\mathrm{BC}$, but the specific sources of these individuals could not be determined.

\section{Skunk Predation}

Predation on seabirds by island spotted skunks had not been documented prior to our work at SCZ (McIver et al. 2009, this study), though this subspecies of spotted skunk only occurs on SCZ and neighboring Santa Rosa Island, as well as historically on San Miguel Island (von Bloeker 1967, Crooks and Van Vuren 1994). Mammalian carnivores do not usually occur on islands (Carlquist 1974); the 2 native carnivores on SCZ are unusual (Crooks and Van Vuren 1994) and may have been brought to the island by Native Americans (Walker 1980, Rick et al. 2009) or rafted to SCZ on debris (Wenner and Johnson 1980). Storm-petrels typically nest at locations on islands that are protected from or free of mammalian predators (Warham 1990, Bailey 1993). At SCZ these locations include sea caves, offshore rocks, and possibly inaccessible cliffs (Carter et al. 2018). It is not understood how small numbers of skunks accessed BC and CPC because high, steep cliffs surround the ocean entrances to these caves, seemingly preventing access by land. We suspect that the skunks somehow ended up in the water (possibly falling from nearby low cliffs) and swam into these caves. Island spotted skunks are active only at night and are specialized in their 
habitat use, utilizing grasslands, coastal sage scrub, chaparral, and scrub oak habitats on the interior portions of the island (Crooks 1994, Crooks and Van Vuren 1994, Jones et al. 2008). Skunks at SCZ have a more specialized diet than island foxes, consisting primarily of mice and insects (Crooks and Van Vuren 1994). In a review of skunk research sources, we found no evidence that skunks utilized intertidal habitats, a habitat use that would allow skunks to regularly gain access to sea caves at SCZ in which ASSP nest. Evidence of skunks and foxes was not observed at the 5 monitored ASSP colonies at SCZ in 1995-2004, nor in 2005-2015 except for the years of skunk predation events at BC (2005) and CPC (2008).

Bailey (1993) reported that several islands in the eastern Aleutians once supported farms for the red fox (Vulpes vulpes) and were largely devoid of birds during the years in which fox rearing occurred. On Baccalieu Island off Newfoundland, Skepkovych (1986) estimated that 12 red foxes killed about 31,000 Leach's Storm-Petrels (O. leucorhoa) in a breeding season. Bailey (1993) suggested that on islands such as Baccalieu, fossorial birds like Leach's Storm-Petrel-which numbered over 6 million birds there-persisted because of their abundance. In comparison, ASSP populations in sea caves at SCZ are small, so it is highly unlikely that ASSP or other fossorial birds (e.g., auklets, guillemots, murrelets) could persist if skunks or foxes had regular access to the colonies. Thus, the predation events by skunks reflect unusual circumstances for a few individual skunks, likely related to a temporary increase in the abundance and distribution of skunks concurrent with a temporary decrease in the abundance of island foxes at SCZ from about 1992 to 2008 (Jones et al. 2008).

\section{Ashy Storm-Petrel Recovery}

Breeding resumed by reduced numbers of $\operatorname{ASSP}(n=19$ nests) at BC in 2006, the year after the skunk predation event. Unfortunately, we had not determined the total number of nests at BC in 2004 for comparison, but late summer nest numbers $(n=25$ on 25 June 2004) were relatively low and had declined since 1995 (Table 5, Fig. 4). The initial recovery in the first few years after skunk predation may have resulted from (1) the larger colony size at $\mathrm{BC}$ compared to $\mathrm{CPC},(2)$ adults that escaped skunk predation by either abandoning an initiated breeding effort (disrupted by the loss of a mate, an egg, or a chick) or not breeding in 2005, and (3) adults returning to BC to breed for the first time, most likely chicks fledged at BC between 2000 and 2004 (assuming high philopatry and 4-6 years before first breeding, as reported for Leach's StormPetrels; Morse and Buchheister 1977). Numbers of nests at BC increased rapidly $(17.7 \%$ per annum) from 2006 to 2015 (Table 5), in sharp contrast to the decline noted between 1995 and 2004. However, little to no increase in numbers of nests was observed between 2010 and 2011 (56 and 58 nests, respectively), which suggested less recruitment of first-time breeders at that time due to reproductive failure at $\mathrm{BC}$ in 2005. The number of nests at BC in $2015(n=98)$ was similar to numbers in $1996(n=97)$, suggesting recovery.

Breeding also resumed at CPC in the year after skunk predation in 2008, with one observed nest in 2009. The total number of nests at CPC in 2007 ( $n=14)$ allowed us to document a $93 \%$ decrease from 2007 to 2009 . In this case, skunk predation had much more severe impacts on the colony because the 29 birds killed were adults, based on the timing of when we salvaged the carcasses (i.e., during the egg-laying period of the season). A lack of recovery was noted between 2009 and 2011, with no nests in 2010 and only 2 nests in 2011, but numbers of nests increased after 2011 (42.6\% per annum from 2009 to 2015), reaching 10 nests in 2015, similar to the colony size in 1995-1997 and $2005(n=11-17)$ (McIver 2002), suggesting recovery. More rapid growth at CPC than BC was partly related to low sample sizes in 2009-2011 $(n=$ 0-2). CPC has a much smaller amount of suitable nesting habitat than $\mathrm{BC}$, and the same number of skunks $(n=2)$ were detected at BC. Thus, a much higher proportion of nesting adult ASSP apparently were killed at CPC. In addition, the smaller colony size from 2003 to 2007 (range 7-11 late summer nests) reduced the number of first-time breeders returning in 2009-2013 to repopulate the colony.

Rapid increases in numbers of nesting ASSP at BC and CPC within a few years of high skunk predation illustrated great resilience by these ASSP colonies to recover from catastrophic events. ASSP mortality may have been greater and recovery slower, however, if 
skunks had not been removed, even though it is doubtful that skunks would have survived at $\mathrm{BC}$ and $\mathrm{CPC}$ over the winter following these events. Other than ASSP, little food for skunks is available in these caves; no vegetation is present, but marine food occurs along the shoreline and small insects are abundant inside caves.

Regular predation by native carnivores can have devastating effects upon a storm-petrel colony. At Saddle Rock, Oregon, Pollard (2008) reported that predation by river otters (Lontra canadensis) and raccoons (Procyon lotor) is suspected to have resulted in the near extirpation of a large Leach's Storm-Petrel colony87,000 birds in 1988 (Naughton et al. 2007) to 3000 birds in 2008-as well as the apparent extirpation of a small colony (a few pairs) of Fork-tailed Storm-Petrels. With apparent changes in the distribution of mammalian predators, Saddle Rock can no longer support a successful and stable storm-petrel colony without significant mammal trapping efforts or other predation prevention methods. At SCZ the removal of a few skunks from sea caves was a logical precautionary management action to protect ASSP. Even though this subspecies of spotted skunk is endemic to the Channel Islands and considered a California species of special concern, the ASSP is also a California species of special concern and largely endemic to California, with nearly half of the world population breeding in the Channel Islands. One skunk at BC in late summer 2005 was never captured and its fate is unknown; it was not alive in the cave in 2006 but may have died in inaccessible parts of the cave or during an attempted swim to escape from the cave. Given the lack of skunks detected at BC after 2005 and at CPC after 2008, annual preventative trapping of skunks at the SCZ sea caves was discontinued in 2015.

\section{Deer Mice}

The small numbers of mice in 3 of 4 monitored sea caves (we could not determine how mice accessed the sea caves) and the lack of direct evidence of predation of ASSP eggs or chicks by deer mice led us to the conclusion that mice were not significant predators, if predators at all. Egg predation by native deer mice has been documented for Scripps's Murrelet (Murray 1980), Ancient Murrelet (S. antiquus) (Gaston 1992) and Rhinoceros
Auklet (Cerorhinca monocerata) (Blight et al. 1999). The loss of at least 1 small chick due to introduced house mouse (Mus musculus) predation was reported for ASSP at Southeast Farallon Island (Ainley et al. 1990). The native St. Kilda field mouse (Apodemus sylvaticus hirtensis) has also been recorded eating Leach's Storm-Petrel eggs and chicks at St. Kilda Island, Scotland (Bicknell et al. 2009). In the latter 2 studies, direct predation upon stormpetrels was not observed but rather inferred based on the discovery of chewed eggs, eggshells, and chicks; thus, scavenging of eggs and chicks also may have occurred. McIver (2002) did not find a relationship between the presence of small numbers of deer mice at BC, CPC, and DSB and reduced hatching success at these colonies in 1995-1997; however, organochlorine pollution did apparently cause many broken, missing, and unhatched eggs in these years (Carter et al. 2008, McIver et al. 2009), which may have masked small impacts from deer mice. As reported for the Fork-tailed Storm-Petrel (Boersma and Wheelwright 1979) and Scripps's Murrelet (Murray 1980), egg neglect during incubation has been observed for ASSP (James-Veitch 1970, Ainley et al. 1990), which would allow a mouse to prey upon a viable egg.

\section{Potential Management Actions}

We are not aware of current research regarding the distribution or abundance of Barn Owls or ravens at SCZ. Predation of ASSP by Barn Owls appears to be reduced at SCZ and currently does not appear to be an issue of management concern. In contrast, predation of ASSP by ravens appeared to be substantial in 2013-2015, as shown by reconnaissance cameras deployed at BC and OR. Thus, we recommend the following research in order to help resource managers develop appropriate and effective management actions at SCZ: (1) continued annual monitoring of ASSP colonies; (2) evaluation of the use of artificial nest sites for ASSP at BC to provide more protected sites; (3) studies of tagged or radio-marked ravens to identify the sources of ravens and, possibly, individual ravens visiting ASSP colonies; (4) evaluation of raven distribution and abundance (see Boarman and Coe 2002); and (5) evaluation of raven responses to human presence (see Marzluff and Neatherlin 2006). Potential management actions regarding 
ravens at ASSP colonies could include hazing, the use of taste aversion agents, or lethal or nonlethal removal (see Boarman 1992, Liebezeit and George 2003, Dinkins et al. 2016). Although preventative trapping of skunks at sea caves was determined to be unnecessary and was discontinued in 2015, annual monitoring of ASSP colonies should be continued to detect any future skunk events so that managers (i.e., CINP and TNC) could respond with trapping efforts. Management actions for deer mice at ASSP colonies at SCZ are likely unnecessary.

\section{ACKNOWLEDGMENTS}

In 1995-2002, funding for this study was provided to Humboldt State University (HSU) by the U.S. Fish and Wildlife Service (USFWS; Ecological Services, Sacramento, CA), U.S. Navy (Legacy Resource Management Program and Naval Air Weapons Station Point Mugu), and California Department of Fish and Game (CDFG; Tax Check-Off Program), with in-kind support from HSU, Channel Islands National Marine Sanctuary (CINMS), the National Biological Service, and the U.S. Geological Survey; major assistance was provided by D. Welsh, R. Helm, T. Keeney, E. Burkett, R. Golightly, J. Miller, E. Cassano, S. Fangman, D. Gilmer, and D. Orthmeyer. In 2003-2005, monitoring was continued by the USFWS (Ventura Fish and Wildlife Office) with assistance by Carter Biological Consulting $(\mathrm{CBC})$ and funding from the CDFG (Habitat Conservation Planning Branch), with in-kind support from CINMS, the USFWS, and CBC; major assistance was provided by E. Burkett and S. Fangman. In 2006-2007, funding was provided to the USFWS (Ventura and Arcata Fish and Wildlife Offices) and CBC by the USFWS (Carlsbad Field Office) on behalf of the Montrose Settlements Trustee Council (USFWS, National Oceanic and Atmospheric Administration [NOAA], National Park Service, California Department of Parks and Recreation, California State Lands Commission, and CDFG), with in-kind support from CINMS and major assistance from A. Little, J. Boyce, D. Lipski, F. Gress, and K. Faulkner. In 2008-2015, funding for nest monitoring was provided to the USFWS (Arcata Fish and Wildlife Office), CBC, Channel Islands National Park (CINP) and the California Institute of
Environmental Studies by the Montrose Settlements Trustee Council and the National Fish and Wildlife Foundation.

In 1995-2005, most vessel support was provided aboard the research vessels Ballena, Xantu, and Shearwater (NOAA skippers J. Miller, E. Cassano, S. Beckwith, M. Kelley, C. Lara, L. Moody, and T. Shinn). In 20062011, almost all vessel support was provided aboard the Miss Devin (skipper R. Fairbanks, Lompoc), and in 2012-2015 support was mostly aboard the Retriever (skippers D. Carlson, T. Shinn, M. Able, and K. Peet; Ventura). Occasional vessel support was provided by: Fuji III (skipper F. Mize, Ventura), Instinct (skipper D. Christy, Newport), Islander and Vanguard (Island Packers, Ventura), and Spirit and Solera (skippers P. Howorth and S. Laniewicz; Santa Barbara).

For their extensive and valuable field assistance, we especially thank D. Cooper, J.R. Gilardi, C. Hamilton, P. Hébert, D. Lipski, G. McChesney, R. McMorran, J. Turner, and D. Whitworth. The preparation of Fig. 1 was assisted by R. Rudolph (NPS). Acknowledgments for the many people who assisted with fieldwork in 1995-2015 are provided elsewhere (McIver 2002, McIver et al. 2009, 2016); also see reports written for the Montrose Settlements Restoration Program at http://www.montroserestoration.noaa.gov/. We thank trappers M. Dennis and K. Randall from CINP for their assistance in 2006.

The findings and conclusions in this article are those of the authors and do not necessarily represent the views of the U.S. Fish and Wildlife Service.

\section{Literature Cited}

Ainley, D.G. 1995. Ashy Storm-Petrel (Oceanodroma homochroa). No. 185 in A. Poole and F. Gill, editors, The Birds of North America. The Academy of Natural Sciences, Philadelphia, PA; American Ornithologists' Union, Washington, DC.

Ainley, D.G., R.P. Henderson, and C.S. Strong. 1990. Leach's Storm-Petrel and Ashy Storm-Petrel. Pages 128-162 in D.G. Ainley and R.J. Boekelheide, editors, Seabirds of the Farallon Islands: ecology, structure and dynamics of an upwelling system community. Stanford University Press, Palo Alto, CA.

Ainley, D.G., T.J. Lewis, AND S. Morrell. 1974. Patterns in the life histories of storm-petrels on the Farallon Islands. Living Bird 13:295-312.

BAILEY, E.P. 1993. Introduction of foxes to Alaskan islands - history, effects on avifauna, and eradication. U.S. Department of the Interior, Fish and Wildlife Service Resource Publication 193, Washington, DC. 
Bakker, V.J., D.K. Garcelon, E.T. Aschehoug, K.R. Crooks, C. Newman, G.A. Schmidt, D.H. Van Vuren, AND R. WOODRofFe. 2005. Current status of the Santa Cruz Island fox (Urocyon littoralis santacruzae). Pages 275-286 in D.K. Garcelon and C.A. Schwemm, editors, Proceedings of the Sixth California Islands Symposium, Ventura, California, December 1-3, 2003. National Park Service Technical Publication CHIS-05-01, Institute for Wildlife Studies, Arcata, CA.

BickneLl, T.W.J., J.B. Reid, ANd S.C. Votier. 2009. Probable predation of Leach's Storm-Petrel Oceanodroma leucorhoa eggs by St. Kilda field mice Apodemus sylvaticus hirtensis. Bird Study 56:419-422.

BILLS, A.R. 1969. A study of the distribution and morphology of the mice of Santa Cruz Island: an example of divergence. Master's thesis, Department of Biology, University of California, Santa Barbara, CA.

Blake, E.W., Jr. 1887. Summer birds of Santa Cruz Island, California. Auk 4:328-330.

Blight, L.K., J.L. Ryder, and D.F. Bertram. 1999. Predation on Rhinoceros Auklet eggs by a native population of Peromyscus. Condor 101:871-876.

Boarman, W.I. 1992. Problems with management of a native predator on a threatened species: raven predation on desert tortoises. Pages 48-52 in J.E. Borrecco and R.E. Marsh, editors, Proceedings of the Fifteenth Vertebrate Pest Conference 1992. University of California, Davis, CA.

Boarman, W.I., AND S.J. CoE. 2002. An evaluation of the distribution and abundance of Common Ravens at Joshua Tree National Park. Bulletin of the Southern California Academy of Sciences 101:86-102.

Boarman, W.I., and B. Heinrich. 1999. Common Raven (Corvus corax). In: A. Poole, editor, The Birds of North America Online. Cornell Lab of Ornithology, Ithaca, NY. https://doi.org/10.2173/bna.476

Boarman, W.I., M.A. Patten, R.J. Camp, and S.J. ColLIS. 2006. Ecology of a population of subsidized predators: Common Ravens in the central Mojave Desert, California. Journal of Arid Environments 67:248-261.

Boersma, P.D., and N.T. Wheelwright. 1979. Egg neglect in the Procellariiformes: reproductive adaptations in the Fork-tailed Storm-Petrel. Condor 81: $157-165$.

Bunn, D.S., A.B. Warburton, and R.D.S. WiLson. 1982 The Barn Owl. Buteo Books, Vermillion, SD.

Bunnell, D. 1988. Sea caves of Santa Cruz Island. NcNally and Loftin Publishers, Santa Barbara, CA.

[CDFW et al.] California Department of Fish and Game, PartNership For Interdisciplinary Studies of Coastal Oceans, Channel Islands National Marine SANCTUARY, AND Channel Islands National Park. 2008. Channel Islands Marine Protected Areas: first 5 years of monitoring: 2003-2008. [Accessed 27 February 2017]. https://nrm.dfg.ca .gov/FileHandlerashx? DocumentID $=31325$

CARLQUist, S.J. 1974. Island biology. Columbia University Press, New York, NY.

Carter, H.R., D.G. Ainley, S.G. Wolf, and A.M. WeinSTEIN. 2016. Range-wide conservation and science of the Ashy Storm-Petrel Oceanodroma homochroa. Marine Ornithology 44:53-62.

Carter, H.R., G.J. McChesney, D.L. Jagues, C.S. Strong, M.W. Parker, J.E. Takekawa, D.L. Jory, AND D.L. Whitworth. 1992. Breeding populations of seabirds in California, 1989-1991. Volume 1, Population estimates. Unpublished draft report, U.S. Fish and Wildlife Service, Northern Prairie Wildlife Research Center, Dixon, CA.

Carter, H.R., W.R. McIver, and G.J. McChesney. 2008. Ashy Storm-Petrel (Oceanodroma homochroa). Pages 117-124 in W.D. Shuford and T. Gardali, editors, California Bird Species of Special Concern: a ranked assessment of species, subspecies, and distinct populations of birds of immediate conservation concern in California. Studies of Western Birds 1:117-124.

Carter, H.R., W.R. McIver, G.J. McChesney, D.L. Whitworth, aND J.R. GILARDI. 2018. Status of Ashy Storm-Petrel breeding colonies at Santa Cruz Island, California, 1912-1998. Western North American Naturalist 78:404-420.

Carter, H.R., M.W. Parker, J.S. Koepke, and D.L. Whitworth. 2015. Breeding of the Ashy StormPetrel in central Mendocino County, California. Western Birds 46:49-65.

Collins, P.W., AND H.D. Jones. 2015. A checklist of birds of the California Channel Islands. Santa Barbara Museum of Natural History, Santa Barbara, CA. 46 pp.

CoOnan, T.J., AND A. Guglielmino. 2012. Island fox recovery program: 2010 annual report. Natural Resource Report NPS/MEDN/NRR-2012/483. National Park Service, Fort Collins, CO.

Crooks, K. 1994. Demography and status of the island fox and the island spotted skunk on Santa Cruz Island, California. Southwestern Naturalist 39:257-262.

Crooks, K.R., AND D. VAN Vuren. 1994. Conservation of the island spotted skunk and island fox in a recovering island ecosystem. Pages 379-385 in W.L. Halvorson and G.J. Maender, editors, Proceedings of the Fourth California Islands Symposium: update on the status of resources. Santa Barbara Museum of Natural History, Santa Barbara, CA.

Crooks, K.R., and D. Van Vuren. 2000. Update on the status of the island spotted skunk. Pages 298-299 in D.R. Browne, K.L. Mitchell, and H.W. Chaney, editors, Proceedings of the Fifth California Islands Symposium, Santa Barbara, California. Santa Barbara Museum of Natural History, Santa Barbara, CA.

Diamond, J.M., AND H.L. Jones. 1980. Breeding land birds of the Channel Islands. Pages 597-612 in D.M. Power, editor, The California islands: proceedings of a multidisciplinary symposium. Santa Barbara Museum of Natural History, Santa Barbara, CA.

Dinkins, J.B., M.R. Conover, C.P. Kirol, J.L. Beck, AND S.N. Frey. 2016. Effects of Common Raven and coyote removal and temporal variation in climate on Greater Sage-Grouse nesting success. Biological Conservation 202:50-58.

Fritz, J., AND K. Kotrschal. 1999. Social learning in Common Ravens, Corvus corax. Animal Behaviour $57: 785-793$.

Gaston, A.J. 1992. The Ancient Murrelet: a natural history in the Queen Charlotte Islands. T. \& A.D. Poyser, London, United Kingdom.

Guthrie, D.A. 1993. New information on the prehistoric fauna of San Miguel Island, California. Pages 405-416 in F.G. Hochberg, editor, Third California Islands Symposium: recent advances in research on the California islands. Santa Barbara Museum of Natural History, Santa Barbara, CA.

Howell, B., AND A. VAn Rossem. 1911. Further notes from Santa Cruz Island. Condor 13:208-210. 
James-Veitch, E.A.T.C. 1970. The Ashy Petrel, Oceanodroma homochroa, at its breeding grounds on the Farallon Islands, California. Doctoral dissertation, Loma Linda University, Los Angeles, CA. 366 pp.

JaniskeE, B. 2010. Creature feature: the Common Raven is an uncommonly intelligent bird. [Accessed $27 \mathrm{Feb}-$ ruary 2017]. National Parks Traveler, Box 980452, Park City, UT 84098. http://www.nationalparks traveler.com/2010/06/creature-feature-common-raven -uncommonly-intelligent-bird5933

Jones, K.L., D.H. Van Vuren, And K.R. Crooks. 2008. Sudden increase in a rare endemic carnivore: ecology of the island spotted skunk. Journal of Mammalogy 89:75-86.

LACK, D. 1968. Ecological adaptations for breeding in birds. Methuen and Company, London, United Kingdom.

Lenton, G.M. 1984. The feeding and breeding ecology of Barn Owls Tyto alba in the peninsular Malaysia. Ibis 126:551-575.

Liebezeit, J.R., AND T. GeORge. 2003. A summary of predation by corvids on threatened and endangered species in California and management recommendations to reduce corvid predation. Unpublished report, Humboldt State University, Arcata, CA.

LinZ, G.M., C.E. KnitTle, And R.E. Johnson. 1992. Home range of breeding Common Ravens in coastal southern California. Southwestern Naturalist 37:199-202.

MacKinnon, C.M. 1988. Population size, habitat preferences and breeding biology of the Leach's StormPetrel Oceanodroma leucorhoa (Viellot) on Bon Portage Island, Nova Scotia. Master's thesis, Acadia University, Wolfville, Nova Scotia, Canada.

Marti, C.D. 1992. Barn Owl (Tyto alba). No. 1 in A. Poole and F. Gill, editor, The Birds of North America. Academy of Natural Sciences, Philadelphia, PA; American Ornithologists' Union, Washington, DC.

Marzluff, J.M., AND T. Angell. 2005. In the company of crows and ravens. Yale University Press, New Haven, CT.

Marzluff, J.M., and E. Neatherlin. 2006. Corvid response to human settlements and campgrounds: causes, consequences, and challenges for conservation. Biological Conservation 130:301-314.

Maxwell, M.R., A. Henry, C.D. Elvidge, J. Safran, V.R. Hobson, I. Nelson, B.T. Tuttle, J.B. Dietz, and J.R. Hunter. 2004. Fishery dynamics of the California market squid (Loligo opalescens), as measured by satellite remote sensing. Fishery Bulletin 102: $661-670$.

Mayfield, R.L., D. Van Vuren, and M.L. Johnson. 2000. Demography of an insular endemic rodent, Peromyscus maniculatus santacruzae, on Santa Cruz Island. Southwestern Naturalist 45:508-513.

McChesney, G.J., And B.R. Tershy. 1998. History and status of introduced mammals and impacts to breeding seabirds on the California Channel and northwestern Baja California Islands. Colonial Waterbirds 21:335-347.

McIver, W.R. 2002. Breeding phenology and reproductive success of Ashy Storm-Petrels (Oceanodroma homochroa) at Santa Cruz Island, California, 1995-98. Master's thesis, Department of Wildlife, Humboldt State University, Arcata, CA.

McIver, W.R., H.R. Carter, R.T. Golightly, G.J. McChesney, D. Welsh, and A.L. Harvey. 2009 Reproductive performance of Ashy Storm-Petrels
(Oceanodroma homochroa) at Santa Cruz Island, California, in 1995-2007. Pages 269-281 in C.C. Damiani and D.K. Garcelon, editors, Proceedings of the Seventh California Islands Symposium, Oxnard, California, February 5-8, 2008. Institute for Wildlife Studies, Arcata, CA.

McIver, W.R., H.R. Carter, A.L. Harvey, D.M. MazurKIEWICZ, AND J.W. MASON. 2016. Use of social attraction to restore Ashy Storm-Petrels Oceanodroma homochroa at Orizaba Rock, Santa Cruz Island, California. Marine Ornithology 44:99-112.

McNeil, R., P. Drapeau, and A. Pierotti. 1993. Nocturnality in colonial waterbirds: occurrence, special adaptations and suspected benefits. Current Ornithology 10:187-246.

Morse, D.H., And C.W. Buchheister. 1977. Age and survival of breeding Leach's Storm-Petrels in Maine. Bird Banding 48:341-349.

Murray, K.G. 1980. Predation by deer mice on Xantus' Murrelet eggs on Santa Barbara Island, California. Master's thesis, California State University, Northridge, $\mathrm{CA}$.

Naughton, M.B., D.S. Pitkin, R.W. Lowe, K.J. So, And C.S. Strong. 2007. Catalog of Oregon seabird colonies. U.S. Fish and Wildlife Service Biological Technical Publication FWS/BTP-RI009-2007, Washington, DC.

Nelson, E.W., and E.A. Goldman. 1931. Six new whitefooted mice (Peromyscus maniculatus group), from islands off the Pacific Coast. Journal of the Washington Academy of Sciences 21:530-535.

Newsome, S.D., P.W. Collins, AND P. Sharpe. 2015. Foraging ecology of a reintroduced population of breeding Bald Eagles on the Channel Islands, California, USA, inferred from prey remains and stable isotope analysis. Condor 117:396-413.

Oro, D., A. De León, E. Minguez, and R.W. Furness. 2005. Estimating predation on breeding European Storm-Petrels (Hydrobates pelagicus) by Yellowlegged Gulls (Larus michahellis). Journal of Zoology 265:421-429.

Pearson, O.P. 1951. Addition to the fauna of Santa Cruz Island, California: description of a new subspecies of Reithrodontomys megalotis. Journal of Mammalogy 32:366-368.

Pergams, O.R., and M.V. Ashley. 1999. Rapid morphological change in Channel Islands deer mice. Evolution 53:1573-1581.

POLLARD, A.M. 2008. The effects of mammalian predators on a southern Oregon colony of Leach's StormPetrels (Oceanodroma leucorhoa). Master's thesis, Department of Biology, University of Oregon, Eugene, OR.

QUiNLAN, S.E. 1983. Avian and river otter predation in a storm-petrel colony. Journal of Wildlife Management 47:1036-1043.

Rick, T.C., J.M. Erlandson, R.L. Vellanoweth, T.J. Braje, P.W. Collins, D.A. Guthrie, and T.W. StaFFORD JR. 2009. Origins and antiquity of the island fox (Urocyon littoralis) on California's Channel Islands. Quaternary Research 71:93-98.

Schuyler, P. 1993. Control of feral sheep (Ovis aries) on Santa Cruz Island, California. Pages 443-452 in F.G. Hochberg, editor, The Third California Islands Symposium: recent advances in research on the California islands. Santa Barbara Museum of Natural History, Santa Barbara, CA. 
SKePKOVYCH, B.O. 1986. A predatory behavior and impact of red foxes (Vulpes vulpes) on the seabird colonies of Baccalieu Island, Newfoundland. Master's thesis, Memorial University of Newfoundland, St. Johns, Newfoundland, Canada. $190 \mathrm{pp}$.

Vermeer, K., K.H. Morgan, and G.E.J. Smith. 1993. Nesting biology and predation of Pigeon Guillemots in the Queen Charlotte Islands, British Columbia. Colonial Waterbirds 16:119-129.

von Bloeker, J.C., JR. 1967. Land mammals of the southern California islands. Pages 245-263 in R.N. Philbrick, editor, Proceedings of the Symposium on the Biology of the California Islands. Santa Barbara Botanic Garden, Santa Barbara, CA.

WaLKer, P.L. 1980. Archaeological evidence for the recent extinction of three terrestrial mammals on San Miguel Island. Pages 703-717 in D.M. Power, editor, The California islands: proceedings of a multidisciplinary symposium. Santa Barbara Museum of Natural History, Santa Barbara, CA.

Warham, J. 1990. The petrels: their ecology and breeding systems. Academic Press, San Diego, CA.
Watanuki, Y. 1985. Moonlight avoidance behavior in Leach's Storm-Petrels as a defense against Slatybacked Gulls. Auk 103:14-22.

WebB, W.C., W.I. Boarman, and J.T. Rotenberry. 2004. Common Raven juvenile survival in a human augmented landscape. Condor 106:517-528.

Wenner, A.M., and D.L. Johnson. 1980. Land vertebrates on the California islands: sweepstakes or bridges? Pages 497-530 in D.M. Power, editor, The California islands: proceedings of a multidisciplinary symposium. Santa Barbara Museum of Natural History, Santa Barbara, CA.

Yosef, R., AND N. Yosef. 2010. Cooperative hunting in Brown-necked Raven (Corvus rufficollis) on Egyptian Mastigure (Uromastyxa egyptius). Journal of Ethology 28:385-388.

Received 28 February 2017 Revised 27 November 2017 Accepted 12 January 2018 Published online 23 October 2018 